\title{
KAJIAN NOVEL NY. TALIS KARYA BUDI DARMA BERDASARKAN PENDEKATAN ORIENTASI PEMBACA
}

\author{
Abdul Rozak ${ }^{1}$, Sobihah Rasyad ${ }^{2}$ \\ Program Studi Pendidikan Bahasa Indonesia \\ Universitas Swadaya Gunung Jati Cirebon \\ Abdurrozak58@unswagati.ac.id, sobihahrasyad58@unswagati.ac.id
}

\begin{abstract}
ABSTRAK
Teks sastra memberikan peluang kepada pembaca menelaah dengan cara yang berbeda. Novel Ny. Talis karya Budi Darma membuka peluang ditelaah berdasarkan pendekatan orientasi pada pembaca. Teks tersebut berisi lubang-lubang yang dapat diisi pembaca. Penelitian ini berfokus pada telaah analisis deskriptif terhadap novel tersebut dengan permasalahan (1) bagaimana penceritaan/konflik yang disajaikan pengarang, (2) bagaimana karakter para tokoh yang terdapat pada novel tersebut, dan (3) bagaimana lokasi dihubungkan dengan terjadinya peristiwa pada teks novel tersebut. Adapun hasil penelitian adalah (1) penceritaan nirkonflik, (2) penokohan bersifat stabil, dan (3) teks ini tidak menggambarkan keterjadian lokasi..
\end{abstract}

Kata kunci: orientasi pembaca, respons pembaca, penceritaan, karakter, lokasi

\section{A. PENDAHULUAN}

Teks sastra memberikan peluang dicermati dari berbagai segi. Keterbukaan sebuah teks sastra dimulai sejak disusun pengarangnya (Rasyad \& Rozak, 2013). Pengarang tidak berpihak. Para pengarang menyampaikan gagasan dengan penceritaan dalam lokasi tertentu, dengan beberapa karakter yang saling berinteraksi. Sudut pandang pengarang dapat berbeda dengan sudut para pembaca. Pengarang telah menyempurnakan cerita pada saat dipublikasikan. Oleh karena itu, pembaca dapat memahaminya berdasarkan pengetahuan, pengalaman, dan perasaan pembaca. Salah satu pendekatan yang beranggapan bahwa pada teks sastra selalu terdapat lubang-lubang yang dapat diisi pembaca adalah pendekatan orientasi pembaca.

Teori orientasi-pembaca menekankan pada unsur pembaca. Makna teks bergantung pada pembaca pada saat proses membaca berlangsung. Karya sastra itu terbuka, ada peluang di dalamnya yang dapat diisi oleh pembaca. Menurut Ingarden (Teeuw, 1984) bahwa karya sastra mempunyai kemandirian, bersifat skematik dan selektif, tidak pernah menciptakan gambar (dunia) yang bulat lengkap dan setia membayangkan kenyataan. Dalam setiap karya sastra terdapat tempattempat tak tentu, atau kosong, hal-hal yang tidak terisi oleh karya itu dan yang pengisiaannya terserah kepada pembacanya, 


\section{DEIKSIS - JURNAL PENDIDIKAN BAHASA DAN SASTRA INDONESIA}

menurut kemampuannya dan seleranya. Jadi, asumsi yang menjadi dasar pemikiran teori orientasi-pembaca adalah ketermasukan pembaca sebagai penentu makna teks.

Di samping itu, unsur yang dijadikan dasar oleh teori orientasi-pembaca adalah fenomenologi, yaitu "The phenomenological theory of art lays full stress on the idea, in considering a literary work, one must take into account not only the actual text but also, and in equal measure, the actions involeved in responding" (Iser, http:/www.citadel.edu/ faculty/leonard/I SER.html). Unsur respons merupakan tanggapan pembaca terhadap gejala yang terdapat dalam karya sastra sebagai teks. Teks bermakna manakala dihubungkan dengan pembaca dalam posisinya yang bebas, tidak terpengaruh oleh niat yang lain. Ketika pembaca bersentuhan dengan teks, ia membawa apa yang ada di kepalanya untuk mengkonstruksikan makna. Inilah yang menjadi acuan utama teori orientasi-pembaca.

Sebuah teks sastra sebagai bentuk narasi pada intinya merupakan rangkaian peristiwa yang disajikan melalui penceritaan, konflik, dan latar (Price dikutip Riedl \& Young, 2010; Rimmon-Kenan, 2002 ; Rasyad \& Rozak, 2016). Teks narasi selalu menceritakan melalui 3 unsur tersebut. Rangkaian narasi itu memberikan peluang pembaca merespons berdasarkan pandangannya. Pandangan pembaca muncul pada saat proses baca berjalan. Pada saat proses itu terjadi berbagai kemungkinan. Iser (1980) berpendapat bahwa proses-baca yang menekankan pada interaksi antara teks dan pembaca sesungguhnya berisi tiga hal penting yaitu, antisipasi dan retrospeksi, akibat pembukaan teks sebagai peristiwa hidup, dan pengaruh akibat kesamaan hidup.

Toeri orientasi-pembaca telah disalahartikan. Orientasi pembaca tidak berarti pembaca berkebebasan dalam menentukan makna. Teori ini tidak mengarah pada kesubjektifan, ungkapan bebas-untuk-semua, arbitrer, komentar personal terhadap teks sastra. Teori ini sebenarnya berfokus pada penemuan makna dalam kegiatan baca (proses baca) sendiri dan pengujian cara pembaca perseorangan atau komunitas dalam hal berpengalaman dengan teks. Teori ini dimunculkan sebagai pencarian jawaban terhadap bagaimakah pembaca bersehubungan dengan pengarang dalam memberartikan teks sastra. Mereka juga, para ahli teori ini kemungkinan menguji signifikansi serangkaian interpretasi yang dijalani pembaca dalam proses baca. Teori ini merupakan loncatan dari teori sebelumnya. Menurut New Criticism hal seperti ini disebut affective fallacy; apa yang dilakukan teks dalam pikiran pembaca? Kenyataannya keberadaan teks hanya dimungkinkan dengan keaktivan pikiran pembaca.

Berhubungan dengan pernyataan di atas toeri orientasi-pembaca menekankan pada peran pembaca. Pembacalah sebetulnya yang menghidupkan teks sastra itu. Pada saat pembaca berinteraksi dengan teks, pembaca membawa serta apa yang ada di kepalanya; pengalamannya, perasaannya, harapannya, identitasnya. Atas dasar inilah prinsip teori ini berkisar teks, pembaca, transaksi, konstruksi, proses baca, konstruksi sosial, komunitas interpretasi. 


\section{DEIKSIS - JURNAL PENDIDIKAN BAHASA DAN SASTRA INDONESIA}

1. Membaca merupakan kegiatan dinamis dan interaktif.

2. Makna muncul dari transaksi antara pembaca dan teks.

3. Respons terhadap teks tidak bersamaan dengan interpretasi terhadap teks.

4. Bahasa sebagai alat untuk memahami makna "kemenjadian" daripada alat ekspresi yang memberikan kenyataan.

5. Makna "kemenjadian" yang paling baik berkenaan dengan realitas konstruksi sosial daripada berkenaan dengan dunia sebagai kenyataan psikologi.

6. Analisis teks, karena itu merupakan aktivitas dinamik, berperhatian pada bahasa sebagai proses yang dinamis, bukan produk yang statis.

7. Analisis, karena itu kongkretisasi, bukan hanya pada apa yang dikatakan bahasa, tetapi pada apa yang diperbuat bahasa.

8. Apa yang dilakukan bahasa tidak berbentuk tunggal, tetapi melaluai proses interaksi. Ia berbentuk dialog. Ego disentralisasikan pada kebertanggungjawaban sosial.

9. Peran pembaca sangat istimewa, berkesempatan pembentukan makna teks yang dibacanya. Peran penulis terkurangi setelah teks itu berhadapan dengan pembaca.

Sebenarnya prinsip dasar teori orientasi-pembaca ada tiga (http://onfocenter.ccit.arizona.edu/ writprog/materials/ 3-6.htm), yaitu

1. Reading is believed to be dynamic and interactive;

2. Meaning emerges from transaction betweeen readers and texts;

\section{Response to texts do not equal interpretation of texts.}

Penelitian ini difokuskan pada analisis teks novel $N y$. Talis karya Budi Darma untuk menjawab masalah (1) bagaimana penceritaan pada novel tersebut, (2) bagaimana karakter disajikan pada novel tersebut, dan (3) bagaimana lokasi dihubungkan dengan terjadinya peristiwa pada teks novel tersebut. Kemudian, hasil analisis direspons dengan teori Iser. Novel karya Budi Darma dipilih karena gagasan yang disajikan dalam novel itu menarik untuk ditanggapi. Gagasan yang disajikan dalam novel itu berhubungan dengan mimpimimpi Indonesia ke depan. Oleh karena itu, novel itu patut ditelaah lebih lanjut. Gagasan-gagasan yang terdapat dalam teks itu perlu dimaknai dan dihubungkan dengan kehidupan kita.

\section{B. METODE PENELITIAN}

Penelitian ini menggunakan metode analisis deskriptif kualitatif. Model yang dipilih adalah analisis domain (Spradley, 1980). Peneliti membaca naskah secara menyeluruh untuk memeroleh gambaran tentang isi untuk menjawab masalah penelitian, yaitu gaya penceritaan, penokohan, dan konflik. Proses pembacaan dilakukan untuk menemukan rangkaian peristiwa yang terdapat pada novel sebagai sumber data. Rangkaian peristiwa dikelompokkan sesuai dengan topik penelitian. Analisis berdasarkan pendekatan orientasi pada pembaca. Pendekatan ini menekankan pada pendapat pembaca tentang isi teks sastra (Iser, 1980; Rosenblatt, 1976). 


\section{HASIL PENELITIAN}

\section{a. Penceritaan}

Penceritaan teks ini datar. Para tokoh mengisahkan hidupnya bergantian. Mereka diberi porsi masing-masing. Penceritaan seperti ini membosankan juga kadangkadang terlihat seperti terpotong-potong atau mungkin teks ini ingin mengisahkan bahwa kisah hidup itu tidak lengkap. Atau mungkin juga untuk memunculkan kepenasaran. Jika yang kedua yang dimaksudkan, teks ini kurang berhasil. Cara seperti ini menjadi monoton. Pembaca harus mengingat sampai di mana cerita Madras, misalnya. Informasi itu disajikan terputusputus.Teks ini menceritakan perilaku apa lagi yang akan dijalankan para tokoh. Pada akhirnya perjalanan meraka itu memang lengkap dengan urutan waktu dalam siklus kisah manusia; lahir, dewasa, meninggal. Jadi, teks ini ingin mengisahkan kisah hidup para tokohnya selengkap-lengkapnya ; sejak lahir sampai dengan meninggal.

Teks ini nirkonflik. Konflik sebenarnya menjadi penting dalam teks narasi. Konflik dalam pengertian persilangan di antara para tokoh yang akan menyebabkan mereka bertambah matang. Teks narasi yang mengisahkan hidup sebenarnya sarat dengan konflik. Konflik dalam kehidupan menjadi media pematangan seseorang. Penambahan dan pengayaan seseorang akan sangat banyak tergantung pada kualitas dan kuantitas konflik yang mereka hadapi. Hubungan Madras dengan ibunya berjalan dengan harmonis. Hubungannya dengan Wiwin juga lancar, tidak pernah bertengkar, begitu juga hubungannya dengan Siti Wedanti. Ada peristiwa yang menunjukkan adanya ketidakcocokan dalam hal pendapat tentang hubungannya dengan Siti Wedanti, yaitu pada saat mereka akan menikah. Sikap Madras yang tidak tetap; kadang-kadang siap menikahi Siti Wedandi, kadang-kadang mundur. Hal ini berkaitan dengan sifat Madras yang sulit untuk berteguh dalam satu sikap yang dipegangnya. Konflik itu tidak mengubah apa-apa. Sifat Madras tetap seperti itu, begitu juga Siti Wedanti seperti semula.

Begitulah Madras menjalani hidupnya dengan datar; tidak pernah dihadapkan kepada situasi yang sulit. Konflik itu ada atau semacam konflik, yaitu pada peristiwa yang dialami $N y$. Talis. Dia dicekam dengan ketakutan-ketakutan berhubungan dengan sikap suaminya yang aneh. Dia ditelantarkan, diasingkan, disiksa. Ny. Talis tidak pernah protes terhadap keadaan itu. Hanya ketegangan sesaat terjadi ketika suami $N y$. Talis berpenyakit aneh dan dirawat di rumah sakit. Keadaan yang tidak stabil menyebabkan rumah sakit repot. Setelah itu tidak ada peristiwa yang menegangkan. Teks ini memang hanya berkisah. Teks ini mengisahkan orang-orang yang mempunyai keistimewaan dalam suasana yang tidak istimewa.

\section{b. Karakter}

Karakter dalam teks narasi-fiksi, $N y$.

Talis (Kisah mengenai Madras) tidak berkembang, begitu adanya, sudah disiapkan penulis. Madras yang baik hati, hidup kurang teratur, cerdas, pintar, gampang mencari duit, mudah mengingat apa yang dipelajarinya, bisa meloncat dari gedung ke 


\section{DEIKSIS - JURNAL PENDIDIKAN BAHASA DAN SASTRA INDONESIA}

gedung, terkenal karena tulisannya dipublikasikan secara internasional. Sifatsifat itu dimilikinya berkat doa ibunya yang menghendaki anaknya menjadi anak soleh. Karakter yang dimiliki tokoh tak berproses. Sifat-sifat itu dimiliki Madras sejak lahir. Madras menjalani kehidupannya; kehidupan yang juga linear. Dia bersentuhan dengan beragam orang yang menguntungkan dia, artinya dia berjalan dalam keseharian hidup sesuai dengan apa yang diinginkannya, dengan apa yang dibayangkannya. Permasalahan yang dia hadapi tidak menantangnya berpikir lama dan menjadikannya matang, lebih matang. Dia memang telah matang.

Ny. Talis juga begitu. Dia memang sudah baik sejak awal. Dia orang yang beruntung. Selepas meninggal orang tuanya dia dititipkan pada keluarga kaya, Raden Mas Ompreng. Kecantikannya menjadi rahmat bagi kehidupannya. Dia dikasihi anggota keluarga itu. Dia dikawinkan oleh Ny. Raden Mas Ompreng dengan laki-laki yang kaya. Ny. Talis menderita dalam perkawinannya. Dia sangat tidak dipedulikan suaminya. Dia sangat tidak dianggap sebagai istri oleh suaminya. Dia disiksa. Suami $N y$. Talis menurut teks itu berhati iblis. Suami Ny. Talis tidak berubah karakternya. Dia tetap sebagai iblis sampai dengan meninggalnya, Begitu pula dengan karakter Ny. Talis yang tetap sabar menghadapi berbagai derita yang dialaminya. Sampai dengan meninggalnya, Ny. Talis tetap menjadi orang yang baik, bersifat menerima. Ketika dibentak-bentak oleh dr. Ratna sehubungan dengan penyakitnya dan ketika dikawinkan dengan dr. Duliman, Ny. Talis tidak menolak.

Jadi, secara umum karakter para tokoh yang terdapat pada teks $N y$. Talis (Kisah mengenai Madras) tidak berubah, stabil. Sejak awal memang begitu. Jika dihubungkan dengan kehidupan, tampaknya kurang relevan, meskipun boleh saja, sastra mempunyai otonomi sendiri yang tidak harus sama dengan kehidupanya nyata. Akan tetapi, setidaknya penglihatan relevansi ini mengarah pada kebermanfaatan teks narasi-fiksi. Bagaimana pun karakter itu dalam kenyataanya berkembang. Tampaknya teks narasi-fiksi ini disiapkan sebagai wahana untuk menyampaikan konsep penulisnya. Secara jelas memang tampak pandangan penulis dalam menerangkan kehidupan melalui pengisahan para tokoh. Dalam hidup ada orang putih yang selalu baik, yang hidup dengan orangorang baik, yang bertahan dengan kebaikan . Dalam hidup ada orang jahat yang merancang berbagai tindakan kejahatan, yang di dalamnya terkandung hati iblis. Orang seperti ini tidak mungkin berubah. Gambaran inilah tampaknya yang ingin dikisahkan dalam teks narasi-fiksi ini. Oleh karena itu, segalanya telah jadi, telah matang. Perubahan hanya terjadi karena waktu. Waktu itu pun berpengaruh kepada fisik.

Dunia makin tua, tapi tidak pernah nampak makin tua. Karena generasi demi generasi datang, manusia tampak selamanya muda.

$N y$. Talis dengan sendirinya, makin

tua.

Sementara itu, dokter, suami Ny. Talis benar-benar sudah surut. 


\section{DEIKSIS - JURNAL PENDIDIKAN BAHASA DAN SASTRA INDONESIA}

Mula-mula dia menderita tremor.

Dengan sendirinya dia tidak akan sanggup mengoperasi.

Siapa pula sekarang yang kenal

Dokter Ratna? Setelah praktek dia

tidak laku.

Dokter Agung juga sudah dilupakan.

Ilmu dia sudah menjadi primitive.

Alat-lat dia juga kuno dan sangat

memalukan. (245-246)

\section{c. Lokasi}

Ny. Talis (Kisah mengenai Madras) berlokasi di Surabaya. Surbaya menjadi tempat terjadinya berbagai peristiwa yang dialami Madras, keluarganya, dan temantemannya. Jenis lokasi/setting yang kedua adalah bersifat sosial. Surabaya nama kota yang dilengkapi dengan berbagai adat istiadat, budaya, lingkungan sosial lainnya yang melengkapi keberadaan Surabaya sebagai sebuah kota. Berdasarkan hal itu semestinya akan terlihat hubungan antara para tokoh, peristiwa dan lingkungan budayanya akan terlihat. Biasanya, dalam kehidupan keseharian, orang akan dipengaruhi oleh kultur setempat dalam berperilaku, dalam bertindak, atau dalam menyikapi apa yang terjadi dalam hidupnya. Bagaimana dengan Madras? Madras bukan nama khas Surabaya. Nama itu berbau India.

Kebetulan pada waktu itu banyak pedagang mendatangkan kain dari Madras. Andaikata pada waktu itu mobil bikinan Inggris sedang gencar di pasaran, nama kamu pasti Inggris. (12-13)

Pemberian nama tokoh cenderung spontan. Bagi ibu Madras nama itu adalah sesuatu yang melintas dalam dirinya pada saat itu. Di samping itu, hal itu menunjukkan adanya keterpengaruhan oleh situasi pada saat itu. Dari sisi inilah nampak bahwa nama itu menjadi bermakna. Nama ibunya berbeda dengan nama anaknya, Nur Aini Kusbandiyah. Nama yang biasa. Banyak orang Indonesia yang bernama seperti itu. Ayahnya yang tidak dikenalnya itu bernama Abdul Murod Markasan. Nama itu berbau Jawa Timur. Ada apa dengan nama? Nama menjadi media penelusuran silsilah yang berujung pada niat si pemberi nama. Nama Madras seperti diberikan ibunya menjadi dasar penglihatan keterpengaruhan situasi yang berlangsung pada saat itu. Ibunya tidak menutup mata atas berbagai peristiwa yang sedang berlangsung pada saat itu. Dia tertarik pada perdagangan. Perdagangan pada saat itu menjadi penting. Banyak perhubungan terjadi melalui perdagangan. Persentuhan antara bangsa yang di dalamnya terdapat budaya. Kebauran budaya itu menjadi penting sebagai pengayaan di antara budaya yang bercampur.

Teks ini secara nyata tidak menggambarkan fenomena kerterjadian peristiwa berlokasi Surabaya, artinya bau Surabayanya tidak terlihat. Teks ini ingin mengisahkan yang lain. Berbagai kisah yang sama sekali tidak membawa tradisi Surabaya sebagai lokasi berlangsungnya peristiwa demi peristiwa. Ciri khas Indonesia muncul pada desa Wonoboyo di Surabaya, nama Lebai Rohman sebagai lebai di Wonosobo. Lebai yang banyak melakukan fungsi penjalanan upacara keagamaan; menikahkan, mengurus janazah (mulai dari memandikannya sampai dengan 


\section{DEIKSIS - JURNAL PENDIDIKAN BAHASA DAN SASTRA INDONESIA}

mendoakannya di kuburan), mengobati berbagai penyakit. Di samping itu, terdapat perselisihan budaya. Lebai, sebuah jabatan di desa, digeser dengan cara formal. Wartawan Draham meneror selebriti. Selebriti menyewa algojo, terjadilah penganiayaan atas wartawan. Resespsi pernikahan di gedung. Semua ini khas Indonesia. Jadi, Surabaya yang telah menjadi kota besar sebagai lokasi percampuran budaya, tidak lagi menampakkan budaya lokal. Hanya peristiwa itu terjadi di Surabaya. Setelah itu berbagai hal dapat berlangsung, budaya global ingin ditonjolkan di Surabaya.

\section{PEMBAHASAN HASIL PENELITIAN}

Inilah impian bangsa kita pada masa yang akan datang. Pada teks ini disebut kota Surabaya. Secara geografis kota itu berada di Indonesia, negara saya. Alangkah bangganya jika negara kita mempunyai orang-orang istimewa seperti Madras, Sidrat, Leni, Wiwin, Wiwini, Ny Talis. Kita sekarang ini sangat memerlukan orang-orang seperti itu; pintar, baik, tidak jahat, terkenal, kreatif, terus menurus mencari, tidak pernah berhenti berkarya.

\footnotetext{
Sidrat sudah menjadi dirigen dan komposer yang sangat terkemuka. Nama Sidrat sudah masuk ke dalam sekian ensiklopedi yang sangat berwibawa. Dialah putra Indonesia pertama yang diundang untuk memimpin orkestra di berbagai negara di Eropa, di Amerika, di Canada, di Jepang, di Australia, dan di mana-mana. (248)
}

Sidrat adalah dirigen yang sangat terkenal. Dia pun seorang komponis yang andal.
Komposisi-komposisi musik Sidrat juga sudah dikumandangkan di gedung-gedung terkemuka di seluruh dunia oleh para maestro yang juga terkemuka. Para maestro sangat puas memainkan komposisi- komposisi musik yang bukan sembarangan. (248)

Sidrat adalah kebanggan untuk kita dan untuk negara. Warga kita memimpin sederetan musisi terkenal dari berbagai dunia. Peristiwa itu terjadi di Surabaya. Kita sudah lama merindukan mempunyai kemampuan memimpin dunia dalam bidang apa pun.

\section{Malam ini dia tampil di kota kelahirannya sendiri, Surabaya. Di hadapan dia sekarang duduk hampir seratus lima puluh pemain instrumen di antara sekian jenis instrumen, lima jenis instrumen tidak lain adalah penemuan dia sendiri. Dan dia sudah memegang hak patent internasional. (249)}

Bukan main jika bangsa kita pada suatu masa mempunyai catatan seperti ini. Kita yakin tidak malu menjadi orang Indonesia seperti kata Taufik Ismail (Malu Aku jadi Orang Indonesia, 1998). Kita bangga mempunyai Sidrat yang mampu memimpin lima ratus musisi dari berbagai negara. Dan bagaimana dia dihormati musisi lain. 


\section{DEIKSIS - JURNAL PENDIDIKAN BAHASA DAN SASTRA INDONESIA}

Tentu kita berkeinginan memiliki manusia sekualitas Sidrat. Manusia cerdas yang membanggakan bangsa kita. Kita belum memiliki manusia sekelas Sidrat; karyanya didiskusikan, didokumentasikan, dianalisis, dijadikan kiblat acuan, dan tentu saja pada setiap pertunjukan dia disaksikan jutaan orang.

Tentu saja saya sangat berharap mempunyai warga yang seperti ini. Mata warga lain yang berlainan benua, berlainan suku, berlainan agama menyatu memandangkan pikiran, perasaan, dan seni kepada bangsa kita karena kita mempunyai orang yang dibanggakan. Sayang cuma satu, hanya Sidrat. Pemian musik dari berbagai bangsa berpartisipasi, diakui dan bangsa kita hanya diwakili seorang saja. Musisi atau siapa pun merasa bangga bermain musik dengan Sidrat. Dengan hanya satu orang bangsa kita menjadi terkenal. Kita memang bangsa yang berani berjalan sendiri. Seperti kata Kang Ajip, bangsa kita berbeda dengan bangsa Jepang. Bangsa kita cenderung untuk individual, bepergian sendirian tidak jadi masalah. Bahkan cenderung menjadi senang tidak ditemani. Bangsa Jepang selalu bepergian berkelompok, cenderung bersamasama dalam menghadapi berbagai masalah. Kebiasaan hidup kita bertolak belakang dengan bambu yang merumpun dan bambu Jepang tumbuh tidak merumpun, tetapi kehidupan mereka berumpun, saling membahu menghadapi musuh, tidak saling menyalahkan. Kita cenderung sebaliknya kesalahan ditimpakan kepada seseorang atau golongan.
Siapakah Sidrat itu?

... tadi ketika wajah Madras

ditembak kamera televisi, dia tidak

hanya disebut sebagai ayah Sidrat.

Sebuah telop di bawah wajahnya nenyatakan, "the famous syndicated columnist of international relations". Di kalangan pers, perguruan tinggi, politisi, dan orang-orang pemerintahan memang mengenal dia sebagai kolumnis sindikasi masalah luar negeri. (262)

Ayah Sidrat adalah Madras. Dia orang yang cerdas juga. Dia orang terkenal. Dia terkenal karena tulisan, ulasannya yang tajam mengenai politik luar negeri. Bangsa kita terbawa baik karena orang seperti Madras ini. Dia tidak bergantung kepada orang lain. "Dua kali dalam satu minggu Madras harus menulis ulasan politik luar negeri. Sekali dia menulis, secara serempak atau dalam waktu yang hampir bersamaan sekian ratus koran dan majalah dalam dan luar negeri memuat ulasan Madras. (262). Kita bangga mempunyai warga yang terhormat karena kepintarannya, karena keluasan pengetahuannya, karena kemampuan pikirannya. Keterkenalan akademik akan sangat diingat orang. Dalam waktu yang lama orang akan membicarakan karyanya meskipun penulisnya sudah lama tiada. Apalagi Madras sudah banyak menulis buku. "Sebagian besar ulasan dia sudah diterbitkan dalam bentuk buku. Sementara itu, dia juga telah menerbitkan lima buku lain." (262). Ini akan menjadi kenangan. Orang pintar itu harus menyiapkan warisan rohani yang memungkinkan digali terus menerus oleh generasi sesudahnya. Ini 


\section{DEIKSIS - JURNAL PENDIDIKAN BAHASA DAN SASTRA INDONESIA}

dilakukan Madras buat masa depan bangsa, buat generasi yang akan datang agar belajar dari yang tua, agar generasi setelahnya tidak belajar dari awal. Di negara kita kini banyak orang yang jadi komentator, banyak bercerita, banyak mengulas berbagai masalah, segala masalah dikupas dari berbagai segi. Setelah itu hilang bersama hilangnya suara. Madras tidak seperti itu. Dia berkeinginan memberikan sesuatu yang berharga buat generasi muda.

Kelahiran Madras yang tidak biasa itu berpengaruh pada sikap dia yang juga tidak biasa. Dia dengan mudah dapat melompat dari gedung ke gedung, dari satu ruang ke ruang lain (14-15). Orang lain tidak akan mampu mengerjakan ini. Dia cerdas dan kecerdasannya berbeda dengan orang kebanyakan. "Banyak teman-teman dia di sekolah yang dia tolong belajar matematika, belajar fisika, balajar biologi, belajar bahasa Inggris, belajar ilmu-ilmu sosial, dan entah apa lagi. Dia sendiri jarang belajar. Bagaimana dia mau belajar kalau buku-bukunya tersebar di sana sini dan sulit dilacak? Tepi dia naik kelas terus. Tepat pada waktunya dia menjadi sarjana, tanpa kesulitan apa-apa. Seluruh nilanya sangat baik." (7). Mungkin untuk saat ini bangsa ini sulit untuk mempunyai anak seperti Madras. Akan tetapi, bukan sesuatu yang mustahil. Kita akan mampu mempunyai anak seperti itu. Saya membayangkan kita akan mempunyai seribu atau sejuta orang yang kecerdasannya seperti Madras.

Seandainya kita memiliki jutaan Madras, negara ini tidak perlu terpuruk dalam ketakberdayaan seperti ini. Semua habis digunakan untuk sesuatu yang tidak tahu untuk apa. Semua yang kita miliki hampir musnah. Kita jarang berbuat untuk masa depan. Kita selalu mengacu kepada kebutuhan kita dan kepada kepentingan kita. Perhitungan-perhitungan tindakan kita selalu salah dalam penerapannya. Saya sedih mengingat hal itu dan saya merasa sangat beruntung bila kita mempunyai madrasmadras kecil yang berwawasan luas. Saya yakin dari keluarga cerdas itu akan lahir juga anak cerdas. Orang yang baik akan bertemu dengan orang baik.

Saya membayangkan bahwa negara kita dipenuhi oleh orang-orang pintar yang baik, yang bijak. Madras yang cerdas; belajar menurut aturannya sendiri dan bisa, banyak menulis. Tulisannya tersebar di seluruh dunia. Dia pernah diundang presiden Filipina karena tulisannya. Tulisan Madras disebarkan ke seluruh negara oleh menantunya yang pandai elektronik. Di nagara kita ada Sidrat, sang maestro, yang sanggup menciptakan berbagai alat instrumen, sanggup meramu berabgai komposisi dengan indah, menjadi orsinalìtas ( =OPPURTUNITY FOR READER TO PICTURE ITEM IN THE TEXT). Menurut Iser menambahkan bahwa, " the literary work has two poles, which we might call the artistic refers to the text created by the author; and the aesthetic to the realization accomplished by the reader" (1980;212). Apa konsekuensinya teks itu terbuka sebagai peristiwa hidup? Kewajiban kita sebagai pembaca adalah mengisinya, karena teks itu mempunyai lubang/gaps "whenever the flow is interrupted and we are led off in unexpected directions, the opportunity is given to us to bring into play our own faculty 


\section{DEIKSIS - JURNAL PENDIDIKAN BAHASA DAN SASTRA INDONESIA}

for establishing connections - for filling in the gaps left by the text itself." (1980:216).

Tugas kita adalah mencari yang kosong dalan teks tersebut. Secara pasti teks itu selalu menganga. Ada bagian yang dapat diisi dengan harapan pembaca. Dalam proses baca antara pembaca dan penulis dimungkinkan adanya ketidaksamaan harapan. Inilah yang menjadi lubang itu. Proses baca adalah interaksi antara teks dengan skema pembaca. Salah satu di antaranya adalah peristiwa hidup. Hidup yang telah dan sedang dialami dengan apa yang tidak pernah dialami dan itu ada dalam teks. Teks narasi-fiksi pada umumnya berisi peristiwa hidup. Hidup tentang para tokoh yang kemungkinan berhubungan dengan kehidupan pembaca. Ketika membaca teks, pembaca membawa apa yang ada di kepalanya. Dalam benaknya tertata skema yang akan mengendalikan arah baca dan arah interaksi dengan teks.

Dalam teks terdapat struktur yang familiar, yaitu struktur yang akrab dengan kehidupan kita. Pada teks terdapat peristiwa yang sering kita temukan dalam kehidupan sehari-hari. Ketika kita berninteraksi dengan teks, kita tidak merasa asing. Banyak bagian yang telah kita pahami. Dengan demikian, kita dapat menelusurinya dengan mudah. Di samping itu, dalam teks terdapat struktur yang tidak familiar. Berbagai peristiwa tidak akrab dengan kita. Interaksi kita dengan teks memerlukan waktu yang tidak sedikit. Kita perlu waktu dalam menggeluti makna sebelum kita mengonstruksikan makna.

Kita dekat dengan berbagai peristiwa yang terdapat dalam teks, $N y$. Talis. Banyak bagian yang pernah saya alami. Apa pengaruhnya? Saya harus mencoba berpikir ulang tentang apa yang saya jalani setelah membaca teks tersebut. Tentang kesabaran Nur Aini Kusbandiyah, ibu Madras dalam menghadapi berbagai hal, termasuk berbicara jujur kepada anaknya. Bagaimana dia mempraktikkan kejujuran dalam kehidupannya (Bekal utama Nur Aini Kusbandiyah adalah kejujuran , 10). Sikap ini menjadikan kita berpikir ulang. Idiom ini sering kita dengar, tetapi dalam mempraktikkannya memerlukan keberanian. Akan tetapi, orang bijak selalu berpikir dengan kematangan. Apa yang akan diperbuat dan apa akibatnya telah dihitung dengan cermat. Nur Ainun Kusbandiyah telah menghitungnya dengan cermat, karena dia termasuk orang yang bijak, orang yang berhati emas. Sifat ini menurun kepada anaknya, Madras (... Madras tetap berhati emas. Sifat-sifat baik ibunya mengalir dalam darah, mendenyut dalam jantung, mendengus dalam nafasnya. Dia terharu menyaksikan orang-orang hina, papa, dan sengsara. Dan dia bukan hanya terharu, tetapi juga menolong mereka. 7).

Hidup itu memang begitu. Sifat-sifat orang tua akan menurun kepada anaknya dengan kelaziman, dengan kebiasaan melakukannya. Dengan cara ini anak akan melihat perilaku orang tuanya. Apa yang kita renungkan setelah membaca bagian ini? Kita harus berpikir lebih jauh, lebih matang, bahwa kebiasaan itu tidak akan muncul dengan sendirinya. Dia harus ditanamkan. Ia harus diusahakan agar menjadi dalam diri kita. Bagiamanapun niat mendidik anak itu harus dibarengi dengan kesediaan kita 


\section{DEIKSIS - JURNAL PENDIDIKAN BAHASA DAN SASTRA INDONESIA}

berkorban dengan menjadikan kita sebagai model.

Dalam kehidupan selalu muncul
peristiwa yang tidak sejalan dengan
keinginan kita. banyak hal yang kita inginkan ternyata tidak terwujud. Kita diharuskan menjalani dengan mencari dan selalu mencari hikmah. Apa yang menimpa kita harus disikapi dengan positif. Madras memberikan contoh bagaimana menghadapi hidup dengan ketenangan. Bagaimana dia menjalani berbagai peristiwa dengan pikiran tenang dan sifat keberterimaan. Dia akhirnya menerima hasilnya. Hidup bahagia dengan istrinya, dengan anaknya, dengan cucunya dan dia pun meninggal dengan tenang. Madras dan istrinya, Santi Wedanti telah lulus menjalani kehidupan ini dengan selamat dan dengan bahagia.

Kita harus belajar dari Madras bagaimana menolak pekerjaan yang tidak cocok baginya. Berbagai fasilitas telah disediakan. Akan tetapi, dia menolaknya. Dia tidak pernah tinggi hati.

\section{Beberapa hari kemudian Ramus datang lagi dengan sikap tergesa- gesa. \\ "Orang muda,kamu tahu, kan? \\ Presiden akan ke Eropa." \\ "Ya." \\ "Kamu tahu maksud saya?" \\ "Ya." \\ "Bagaimana kalau kamu yang \\ berangkat?" \\ "Tidak." \\ "Apa?" \\ "Tidak."}

Ramus mendelong sedih.

"Orang tua, dengan saya baik-baik. Saya tidak mau jadi penipu. Saya tahu apa yang kamu katakan mengenai artikel-artikel saya. Kamu memuji-muji. Pembaca juga memujimuji. Kamu minta saya terus menulis. Pembaca juga demikian. Kamu senang, pembaca senang. Kamu kira saya senang? Tidak. Saya sedih. Ketahuilah, orang tua, saya menulis asal menulis. Tidak benar saya punya pandangan jauh ke depan. Saya hanya ngawur. Apakah saya harus terus menipu? (90)

Kita harus meniru semangat Madras. Dia selalu menyiapkan berbagai tulisan dalam waktu tertentu. Dia secara teratur menulis untuk berbagai majalah dalam dan luar negeri. "Dua kali dalam satu minggu Madras harus menulis ulasan politik luar negeri. Sekali dia menulis, secara serempak atau dalam waktu yang hampir bersamaan sekian ratus koran dan majalah dalam dan luar negeri memuat ulasan Madras. (262)". Kegiatan ini menunjukkan keberlanjutan olah pikir dan itu menunjukkan peningkatan pengetahuan. Pada masa kini banyak fasilitas, tetapi kurang ditunjang dengan kemauan dan motivasi yang tinggi. Saya harus belajar dari Madras tentang keberterusan dan ketekunan menulis.

Madras, debu, dan wanita menjadi paduan yang aneh dalam teks ini. Artinya berhubungan menjadi kisah mengenai orang yang mempunyai kesaktian dan berkemampuan mempelajari apa pun tanpa guru. Jadi, teks ini sebenarnya mengisahkan sesuatu yang sederhana. Ada oarang yang menganggap dirinya seperti debu. Ada orang yang bermimpi menjadi debu. Ada orang 


\section{DEIKSIS - JURNAL PENDIDIKAN BAHASA DAN SASTRA INDONESIA}

yang berkemampuan komplet (melukis, menyanyi, main sulap).

Ada apa dengan debu? Mungkin hidup ini seperti debu; ringan, mengambang, mengawan, mendarat, menempel, cepat, sangat cepat, lambat, melambat, sangat lembut. Semuanya tergantung pada angin. Jadi, debu itu bergantung kepada angin. Dari sanalah kehidupan; mulai dari debu kembali menjadi debu. Nasib, takdir, untung, jodoh, dan akhirnya meninggal. Semuanya telah diatur. Kita berkemauan. Kita berkemampuan. Akan tetapi, tetap bergantung kepada yang mempunyai segalanya, Tuhan Yang Mahakuasa.

\section{Setiap hari dia melihat debu beterbangan. Dan setiap hari dia berhadapan dengan alam. Sering dia mendengar turun hujan mendayu, melihat jenazah diangkut ke makam dan merasakan panasnya siang dan dingginya malam (1)}

Chairil Anwar menyinggung debu ini ketika menyaksikan neneknya meninggal.

\section{Nisan \\ Untuk nenekanda \\ Bukan kematian benar menusuk kalbu \\ Keridlaanmu menerima segala tiba. Tak kutahu setinggi itu atas debu dan duka maha tuan bertakhta.}

Rupanya kehidupan ini seperti debu. Ia beterbangan sejalan dengan arah angin. Kita hanya mengikutinya. Hidup kita telah diatur takdir yang telah ditentukan-Nya. Kita tidak bisa menghindar. Akan tetapi, kita tidak tahu akan ke mana dan sampai di mana. Kapan debu itu mendarat di tanah dan kembali menjadi tanah adalah menjadi misteri dan menjadi rahasia bagi kita. Segalanya telah diatur oleh Allah. Kita sekedar menjalaninya.

Pengarang teks ini sudah menyiapkan kata debu itu untuk orang-orang yang menjalani berbagai peristiwa dalam teks ini dan dalam hidup ini. Madras dapat berjalan dengan ringan dari gedung ke gedung. Dia dapat berjalan di atas tali. Dia cepat beradaptasi, begitu menempel dia dapat berbuat sesuai dengan yang ditempelinya. Ketika berkenalan dengan Santi Wedanti yang penyanyi, Madras dapat menyanyi dengan baik. Sifat dia menurun kepada anaknya yang kedua, Sidrat. Pada saat berkenalan dengan Wiwin yang pelukis, dia dapat melukis dengan baik. Sifat ini menurun kepada anaknya yang pertama, Wiwin. Debu itu mudah dalam menerima apa pun. Madras mempunyai kamampuan dalam menyimak dan mengingat apa pun. Dia dapat merasakan sesuatu bakal terjadi. Jadi, Madras orang istimewa yang berada di ketinggian karena dia adalah debu.

Ny. Talis juga debu. Dalam waktu yang bersamaan dia mampu merias pengantin dengan sempurna. Dia dapat meloncat dari satu tempat ke tempat lain dengan mudah. Semua orang melihat dia berada di tempat pesta perkawinan. Pesta itu dapat 2 atau 3 dalam satu malam. Jadi, debulah yang berkemampuan seperti itu. Orang biasa tidak mungkin. Saya memahami niat penulis karena penulis menyiapkan tokoh yang dapat menjalani hidup kini yang semakin cepat pergerakannya.

Pengarang memasukkan unsur lain, yaitu burung. Burung aneh ini selalu 


\section{DEIKSIS - JURNAL PENDIDIKAN BAHASA DAN SASTRA INDONESIA}

mengikuti pergerakan Ny. Talis dan Madras. Burung itu hewan yang mampu dalam kecapatan tinggi terbang, melayanglayang di udara seperti debu. Perpaduan ini menjadi penting karena menjadi pasangan yang ideal. Mungkinkah pergerakan $N y$. Talis yang cepat itu karena dibantu oleh burung. Mungkinkah langkah-langkah Madras yang cepat itu dibantu burung aneh. Burung diidentikkan dengan media yang kini dapat membantu manusia dalam berkomunikasi dengan dunia luar. Kecepatan menyadap informasi memerlukan media yang canggih. Batin kita, pikiran kita harus beterbangan menjalani kehidupan yang akan datang. Madras yang tidak hanya fisiknya mampu berlompatan, tetapi juga jangkauan pikirannya ke masa yang akan datang. Dalam arti fisik mungkin saja orang mempunyai kemampuan untuk berloncatan di atas pohon seenaknya. Menurut saya debu itu menjadi penting ketika kita mendudukkan sebagai sesuatu yang bersifat cepat dalam meniti kehidupan ini agar tidak ketinggalan orang lain dan oleh bangsa lain.

\section{E. SIMPULAN}

a. Gaya bercerita teks cerita ini seperti berkisah tentang gagasan membangun bangsa yang bermartabat (Indonesia maksudnya). Kisah-kisah dalam teks ini diceritakan nirkonflik, tidak ada peristiwa yang menjadikan kematangan para tokohnya. Para tokoh sudah disiapkan. Para tokoh cerdas karena lahir dari orang tua yang cerdas. Mereka disiapkan untuk melakukan hal-hal besar untuk kebesaran negaranya. Mereka beraktivitas dalam berbagai peristiwa,; wartawan dan pemain musik. Oleh akrena itu, gaya bercerita cenderung menjelaskan aktivitas para tokoh melalui berbagai peristiwa dan para tokoh tidak sulit menjalankan perannya karena telah disiapkan prangkat yang terdapat pada dirinya.

b. Karakter tokoh pada cerita ini datar karena mengedepankan gagasan ciri khas tokohnya yang luar biasa. Karakter para tokoh digunakan sebagai alat menyampaikan gagasan penulis. Pengarang mengurai cita-cita negara bermartabat dengan para tokoh berpikiran global. Penggunaan simbol debu merujuk pada kecerdasan pengarang mewakili gagasannya yang bergerak kian kemari dengan bebas dan dapat terbang di atas bumi. Para tokoh dapat terbang dengan tidak diceritakan asal-muasalnya. Debu itu menjadi media pengarang menyampaikan gagasan melalui peristiwa yang dilakoni tokoh berkarakter tetap, datar. Karakter datar tidak melanggar ketentuan, karena pengarang mempunyai kebebasan menyajikan sesuai dengan gagasan yang akan disampaikannya.

c. Lokasi pada cerita mempunyai peran dasar. Peristiwa tidak mungkin berjalan tanpa wilayah tempat cerita itu berlangsung. Pembaca akan mempertanyakan di mana lokasi cerita itu terjadi. Aksi tokoh perlu dasar berpijak untuk berperilaku. Lokasi pada cerita ini berada di sini, Indonesia (Surabaya) dan global. Lokasi pada cerita ini tidak terkait dengan nama para tokoh secara jelas. Nama tokoh utama merujuk pada nama asing, Madras, Sidrat, $N y$. Talis. Nama itu disiapkan untuk 


\section{DEIKSIS - JURNAL PENDIDIKAN BAHASA DAN SASTRA INDONESIA}

masuk ke dunia global, meskipun kelahiran Surabaya.

\section{F. DAFTAR PUSTAKA}

Darma,B. (1996). Ny. Talis (Kisah mengenai Madras). Jakarta : Grasindo.

Fokkema, D.W. \& Elrud, K.I. (1998). Teori Sastra Abad Kedua Puluh. Jakarta : Gramedia.

Hae, N.Z. (1966). Resensi Buku Ny. Talis. http://www.hamline.edu/apakabar/ba sisidata/11/13/0037.html, 12/3/2002.

Hall, A.M. (2002).Reader Response Theory. http://infocenter.ccit.arizona.edu/ writprog/mat erials/3-6.htm, 10/21/2002

Iser, W. (1980). The Act of Reading.

Baltimore : The John Hopkins University Press.

Lye, J. (2001). Contemporary Literary

Theory. Brock University St.

Catharines, Online.

Lye,J. (1996). The Problem of Meaning in

Literature.

http://www.brocku.ca.english/jlye/m eaning.html, 1/24/02

Newton, K.N. (1990) Interpreting Texs (Menafsrikan Teks).Terjemahan Soelistia (1994). Semarang : IKIP Semarang Press

Probts, R.E. Pedagody. http://www.usi.edu/libarts/english/pe d979/htm., 12/17/00.

Rasyad, S. \& Rozak, A. (2016). Pembelajaran Sastra Berbasis Teks. Yogyakarta : Framepublishing

Rasyad, S. \& Rozak, A. (2016). "Pola Akhir Empat Cerita Pendek" Metasastra, Jurnal Penelitian Sastra, Volume 7,
Nomor 2, Desember 2014.

Terakreditasi Nomor :594/AUI/P2MI-L/06/2013

Reader-Response Theory and Criticism.

http://www.press.jhu.edu/books/hopk ins guide to theory/readerresponse theory and criti... 10/19/2002.

Rield, M. \&. (2010). Narrative Planning: Balancing Plot and Character. Journal of Artificial Intellegence Research 30, 217 - 268.

Rosenblatt, L.M. (1976). Literature as Exkploration. New York:The Modern Language Association of America

Rosenblatt, L.M. (1978). The Reader, the Text, The Poem. Carbordale, IL : SIUP.

Rosenblatt, L.M. (1988).Writing and Reading : The Transactional Theory. Technical Report N. 13. University of California, Berkeley CA 94720

Selden, R. \& Peter, W. (1993). Contemporary Literary Theory. The University Press of Kentucky.

Spradley, J.P. (1980). Participation Observation. New York Orlando : Harcourt Brace Jovanovich College Publishers

Teeuw, A. (1983). Membaca dan Menilai Sastra. Jakarta : Gramedia.

Teeuw, A. (1984). Sastra dan Ilmu Sastra Pengantar Toeri Sastra. Jakarta : Pustaka Jaya.

Tompkins, J.P. (eds). Reader-Response Criticism : From Formalism To PostStructuralims. Baltimore and 


\section{DEIKSIS - JURNAL PENDIDIKAN BAHASA DAN SASTRA INDONESIA}

London : The Johns Hopkins

University Press.

Wimsatt \& Beardsley. Reader-Response

Criticism.

http://www.neiu.edu/ edepartm/dep/

profs/scherm/html/readers.htm.

$\underline{10 / 20 / 2002}$ 